\title{
İdarecilerin Yönetim Kadrolarını Tercih Etme Sebepleri ve Yönetici Seçimi İle İlgili Görüşlerinin İncelenmesi ${ }^{1}$
}

\author{
İlhan PEÇE $^{2}$ ve Fazilet TAȘDEMİR ${ }^{3}$
}

\section{Öz}

$\mathrm{Bu}$ araştırma devlete ait ortaöğretim kurumlarında görev yapan idarecilerin yönetim kadrolarını tercih etme sebepleri ve yönetici seçimi ile ilgili görüşlerinin incelenmesi amacıyla gerçekleşmiştir. Bu araştırma nitel araștırma deseninde kurgulanmış olup, betimsel analiz modelindedir. Veri toplamak için amaç doğrultusunda hazırlanan anket ve yarı yapılandırılmış görüşme formu kullanılmıştır. Anket formu 2019-2020 eğitim öğretim yllında Rize il merkezdeki ortaöğretim kurumlarında görev yapan 80 idareciden 74 'üne uygulanarak görüș ve düșünceleri alınmıștır. Çalıșma evren üzerinden yürütülmüştür. Görüşme ise basit seçkisiz örnekleme yöntemiyle evrenden çekilen 18 yöneticiyle gerçekleştirilmiştir. Araş̦ırmanın bulgularına göre idarecilerin yönetici kadrolarını tercih etmesinde eğitimin kalitesini artırma isteği, demokratik bir okul kültürü oluşturma isteği, öğrenme ve kendini geliştirme isteği, iletişim becerilerinin güçlü olması, yöneticilik tecrübesinin olması, liderlik özelliklerine sahip olunmasının daha sık vurgulandığ1 görülmüştür.

Anabtar Kelimeler: Yönetici, Yönetici seçimi, Objektif değerlendirme, Mülakat sınavı, Kurum deneyimi

\section{The Reasons for the Preference of the Administrative Staff of and Investigating Their} Opinions Regarding the Manager Selection

\begin{abstract}
This research was carried out in order to examine the opinions of administrators working in state-owned secondary education institutions about the reasons for choosing administrative staff and about the selection of managers. This study has been conducted in qualitative research format and is in a descriptive analysis model. İn order to gather data for the study, questionnaires and semi-structured interview forms were used. The questionnaires was realized with 74 out of 80 administrators who have been working at public high schools in central Rize in the academic year of 20192020. As a result, their opinions and thoughts regarding the study were obtained. The interviews were conducted with 18 administrators who withdrew from the population form using simple random sampling method. According to the findings of the study, it was seen that the desire to increase the quality of education, the desire to create a democratic school culture, the desire to learn and develop oneself, having strong communication skills, having managerial experience, and having leadership qualities were emphasized more frequently when administrators prefer their administrative staff.
\end{abstract}

Key Words: Manager, Manager selection, Objective evaluation, Interview exam, Institutional experience

\section{Atıf İçin / Please Cite As: \\ Peçe, İ. ve Taşdemir, F. (2021). İdarecilerin yönetim kadrolarını tercih etme sebepleri ve yönetici seçimi ile ilgili görüşlerinin incelenmesi. Manas Sosyal Araştrmalar Dergisi, 10(1), 123-135.}

Geliş Tarihi / Received Date: 10.08.2020

Kabul Tarihi / Accepted Date: 24.09.2020

\footnotetext{
${ }^{1}$ Bu çalışma, Recep Tayyip Erdoğan Üniversitesi Sosyal Bilimler Enstitüsü Eğitim Yönetimi Teftişi ve Planlama Bölümü yüksek lisans programında hazırlanan "İdarecilerin Yönetim Kadrolarını Tercih Etme Sebepleri ve Yönetici Seçimi ile İlgili Görüşlerinin İncelenmesi" adlı yüksek lisans tezinden üretilmiştir.

2 Müdür Başyardımcısı - Rize Fatih Anadolu Lisesi, cogr34@hotmail.com

(D) ORCID: 0000-0003-4325-6674

${ }^{3}$ Dr. Öğr. Üyesi - Recep Tayyip Erdoğan Üniversitesi Eğitim Fakültesi, fazilet.tasdemir@erdogan.edu.tr

iD ORCID: 0000-0002-0430-9094
} 


\section{Giriş}

Ülkelerin eğitim sistemleriyle gelişmişlik düzeyleri arasında yakın bir ilişkiden bahsetmek mümkündür. Eğitim alanında yaşanan gelişim ve ilerlemeler beraberinde ekonomik büyümeyi sosyal ve siyasal gelişmeyi getirmektedir. Eğitim dalga etkisi yaparak yalnızca eğitilen kişiyi değil, kişiden başlayarak aileyi, çevreyi ve daha sonra da toplumun tamamını etkiler (Kaya, 1989). Temel konusu insan olan eğitim yönetimi ve eğitim yönetiminin alt dalı sayılan ve daha dar kapsamda olan okul yönetiminin asıl amacı kişileri bütün yönleriyle geliştirmek, ilgili eğitim politikaları ve örgütün amaçları doğrultusunda yaşatmaktır (Eren, 1991).

Eğitim sisteminin temelini oluşturan okullarda geleceğin temsilcisi olan çocukların eğitim öğretim faaliyetleriyle bilgi, beceri ve davranışlar kazanarak sağllklı ve verimli bir şekilde yetişmeleri amaçlanmaktadır. Okullarda gerçekleşen eğitim-öğretim faaliyetlerinde birinci derecede sorumlu okul yöneticileridir. Okul yöneticileri sahip oldukları bilgi, tecrübe ve davranışlarılyla okul paydaşlarını oluşturan başta öğrenci ve öğretmenler olmak üzere personel ve veliler üzerinde etkili olmaktadır. Bu kritik görev ve sorumlulukları üstlenen okul yöneticilerinin belirli yeterliliklere sahip olması gerekmektedir (Töremen ve Kolay, 2003). Eğitim yöneticilerinin gerekli bilgi, beceri, tutum, davranıs, ilgi, irade vb. yeterliliklere sahip olması kurumların mevcut fiziki ve beşeri kaynakları etkili ve verimli kullanarak hedeflerine ulaşmasını sağlayacaktır (Peker, 1994).

Maarif Teşkilatına Dair 789 Sayılı Kanunun 12. maddesinde "meslekte esas olan öğretmenliktir" vurgusu yapılmıştır. Bu kanun maddesine göre öğretmenler arasından eğitim yöneticilerinin seçimi yapilacak, istenmesi durumunda da eğitim yöneticileri tekrar öğretmenliğe geri dönebilecektir (Taymaz, 1986). Öğretmenler arasından seçilecek okul yöneticilerinin, okul yönetimi hakkında bilgi ve beceriye sahip olması ya da bu bilgileri öğrenmesi gerekmektedir. Aksi hâlde okul hedeflerini etkili şekilde yerine getirilmesi zorlaşacak ve aksaklıklara neden olacaktır (Bursalıŏlu, 2011). Bu nedenle eğitim öğretim plan ve programlarının hazırlayan, eğitimin bütününe etki eden kararlar alan, merkez teşkilatından taşra teşkilatına tüm yöneticilerin atama ve görevlendirmelerinde, yapacakları görevin niteliğine göre bazı ölçütlerin belirlenmesi gereklidir (Kaya, 1986).

Eğitim yönetimi, eğitim sistemi içerisinde gün geçtikçe önemi artmaktadır. Eğitim yöneticilerinin de önemi artmakta ve eğitim liderleri olarak kabul edilmektedir. Eğitim yöneticiliğinin meslek olma yolunda gelişme kaydetmesi, yönetici seçimi için objektif ölçütlerin getirilmesi, eğitim yöneticilerinin hizmetiçi eğitimlere tabi tutulması, yetki ve sorumluluk arasındaki dengenin sağlanması gibi konular her geçen gün önemli hâle gelmektedir (Taymaz, 2003). Ancak eğitim yöneticiliğinin kurumsallaşıp bir meslek hâline dönüşmesi tam olarak gerçekleşememiştir. Eğitim yöneticiliğinin bir meslek hâline dönüşmesini engelleyen en önemli faktör öğretmenlik ve yöneticiliğin birbirinden ayrılmaması, görev ve sorumluluklarının birbirine karışmasıdır. Bu ayrışmanın yapılamaması öğretmen yönetici kavramını ortaya çıkartmıştır. Aynı kişinin hem öğretmen hem de yönetici olması farklı görevleri üstlenmesini gerektirmektedir. Üstlenilen bu görevlerin çakışması, görev karmaşasının oluşmasına neden olacaktır. Bu görev karmaşası eğitim yöneticisinin gücünün azalmasına, olumsuz etkilenmesine kısacası yıpranmasına sebebiyet verecektir. $\mathrm{Bu}$ yüzden eğitim yöneticilerinin alanında başarıll, bilgi ve beceri seviyesinin yüksek olması için mesleğe uygun olarak yetiştirilmeleri sağlanmalıdır (Bursalıoğlu, 2002).

Okul yöneticiliği, geçmişten günümüze daha karmaşık bir hâl almışır. Bu nedenle de okul yöneticilerinin birçok alanda liderlik özelliğini taşımaları gerektiği söylenebilir. Günümüzde okul yöneticilerinin yenilenen ve değişen dünya ihtiyaçlarına cevap verebilmek için daha donanımlı ve daha aktif olmalar1 gerekmektedir (Gümüşeli, 2001). Okul yöneticileri sadece okuldaki idari işlerin yürütülmesinden sorumlu kişiler olmamalıdır. Bunun yerine yeniliğe açı değişimi savunan ve yönlendiren, ufku geniş, çağdaş eğitim anlayışına sahip kişiler olmalıdır (Özden, 2002). Aynı şekilde öğrenme yeteneğine de sahip olmalıdır. Öğrenme yeteneğine sahip olan yöneticiler yeni bilgi becerileri daha kolay öğrenebildiği gibi yeni gelişmelere de daha kolay adapte olur (Erdoğan, 2006). Ayrıca okul yöneticileri ileri görüşlü olup gelecekteki eğilimleri iyi belirlemek zorundadır (Çelik, 2012).

Etkili bir okul yöneticisi yeni fikirlere açık, vizyonu geniş, girişimci ruha sahip, değişim ve dönüşüme açık, hedeflerin farkında olan ve sorunların üstünü kapatma yerine sorun çözücü özelliklere sahip olması gerekmektedir (Balc1, 1993). Yöneticilerin yaratıc1 özelliklerinin de olması gerekmektedir. Yaratıc1 özelliğe sahip yöneticiler monotonluğu sevmeyen, araştırmacı, yeniliklere açık yeni arayışlar içinde olan, irdeleyen, bağımsız olmayı seven, sıradanlıktan hoşlanmayan, sorunlarla mücadele etmeyi seven, esnek ve sorumluluk alma konusunda cesur kişilerdir (Sungur, 1992). 
Okul yöneticilerinin yetiştirilmesinin önünde bazı sorunlar vardır. Bunların başında eğitim sisteminin merkeziyetçi yapıda olması ve yönetici yetiştirme yerine okul lideri ya da eğitim lideri yetiştirilmesine dair bir çalışma içerisine girilmeyişi gösterilebilir (Korkmaz, 2005). Türk Eğitim Sisteminin merkeziyetçi bir yapıda olması otoriter yönetim anlayışını ve katı hiyerarşik sistemi etkili kılmışıı. Bu da eğitim sisteminin genelinde olduğu gibi okul yönetiminde de okul yöneticilerinin yetkilerinin azalmasına, yönetim anlayışındaki özgürlüklerin kısıtlanmasına yol açmışır (Memduhoğlu, 2007).

Kısacası yöneticilerin mevcut yetkileri bakımından merkeziyetçi eğitim anlayışından dolayı üst makamlara bağımlılığı daha çok arttırmıştır (Okçu, 2011). Ayrıca eğitim yöneticilerinin alanıyla ilgili eğitim ihtiyaçlarının da iyi bir şekilde tespit edilemeyişi de önemli bir sorundur. Bu ihtiyaçların iyi bir şekilde belirlenememesi hazırlanacak yönetici yetiştirme programlarının sorunlu ve eksik oluşmasına yol açmaktadır. Bu durum okul yöneticilerinin mesleki kalitesini olumsuz yönde etkilemektedir (Cemaloğlu, 2005).

Yöneticilerin yerine getirmeleri gereken bazı önemli görevleri bulunmaktadır. Okul yöneticileri, örgüt içerisindeki kişilerin bireysel çabalarından daha fazla faaliyet göstermesi gerekmektedir. Geniş bir zaman aralı̆̆ında meydana gelen gelişmeleri yönetme ve bu gelişmelerin yönünü belirleme kudretini gösterme de yöneticinin önemli görevlerindendir (Drucker, 1974). Okul yöneticisi öğrencilerin her yönüyle kendilerini geliştirdikleri uygun öğrenme alanlarını oluşturmakla da görevlidir (Balc1, 1993). Diğer önemli bir görev ise madde ve insan kaynaklarını etkili ve verimli şekilde kullanarak okulun belirlemiş olduğu hedeflere ulaşmasını sağlamaktır (Taymaz, 1986).

Öğretmen olmak, eğitim yöneticisi ya da okul yöneticisi olmak için zorunluluktur. Aynı zamanda okul yöneticisi olmak için öğretmen olmak yeterlidir. Yani okul yöneticisi olmak isteyen bir kişi ilave bir eğitim alma zorunluluğu olmadan bu görevi gerçekleştirebilir. Bu düşünce ve uygulama günümüzde de devam etmektedir (Milli Eğitim Bakanlı̆̆1 [MEB], 1993). Bu açıklamadan da anlaşılacağı üzere MEB'in okul yöneticilerine yönelik gerek göreve başlamadan önce gerekse görev yaptı̆̆ dönem içerisinde yetiştirmeye yönelik bir eğitim endişesinin olmadığı görülmektedir. Böyle bir endişenin olmayışının iki önemli nedeni vardır. Bunlardan ilki öğretmenlik mesleğinde başarılı olan bir kişin okul yöneticiliğinde de başarılı olacağı yönündeki geleneksel düşüncedir. İkincisi ise hazırlanan yönetici seçme siteminin en iyi yöneticileri seçtikleri yönündeki inanıştır (Açıkalın, 1998). Ancak bu düşünce ve uygulama yanlıştır. Çünkü eğitim yöneticisi olacak kişilerin üniversiteden mezun olmaları ya da genel, klasik öğretim kurumlarında eğitim almaları yeterli değildir. Bu eğitim dönemlerinde yönetim ve yöneticilik hakkında eğitim alan kişiler daha sınırlı bilgiye sahip olmaktadır. Bunun için eğitim yöneticiliği yapacak kişilerin göreve başlamadan önce gerçekleştirecekleri görev konusunda bilgi ve becerilerini arttıracak bir eğitimden geçmeleri gerekmektedir (Tortop, 1994). Buradan da anlaşılacağı üzere eğitim yöneticilerine eğitim vermenin amac1 kamu yönetiminin çağdaş düşüncelere uygun olacak şekilde gelişmesine etki edecek kişilerin yönetim alanında donanımlı hâle gelip bu alanda uzmanlaşmasını sağlamaktır (Kalkandelen, 1985).

Kişilerin mesleğini, toplumdaki statüsünü, bireysel ve toplumsal kimliğinin oluşmasını etkileyen ve kısacası toplumun geleceğine yapılan en önemli yatırım arac1 olarak görülen eğitim faaliyetlerinin gerçekleştiği eğitim kurumları oldukça önemli bir yere sahiptir. Okul yöneticileri, bu kurumların yönetilmesi, ögrencilerin gelişimlerinin izlenmesi ve değerlendirilmesi, akademik başarılarının takip edilmesi, çalışanların motive edilmesi, uygun okul ikliminin ve güçlü okul kültürünün oluşturulması, okul içinde ve çevreyle etkili iletişimin sağlanması gibi birçok görevi üstlenmektedir. Okul yöneticileri bu gibi görevleri üstlenmesinden ötürü son derece önemli statüye sahiptir. Okul yönetici kadrolarında görev yapmak isteyen kişilerin, yönetici kadrolarının tercih edilme sebeplerini öğrenmeleri ve bu bilince sahip olarak tercih etmeleri yönetici adayları açısından yararlı olabilir. Ayrıca bu önemli görevi üstlenen yöneticilerin seçiminde kullanılacak değerlendirme ölçütlerinin çok iyi tespit edilmesi, dikkatli ve seçici davranılması gerekmektedir. İdarecilerin seçimi konusunda yaşanan eksiklik, aksaklık ve sorunları daha iyi gözlemleyebilen bizzat işin içinde yer alan kişilerin görüş ve önerilerinin alınması oldukça önemlidir. Eğitim kurumlanında görev yapan idarecilerden elde edilecek görüss ve öneriler ileride hazırlanabilecek yeni yönetici görevlendirme yönetmeliği ve yönetici yetiştirme programına de temel oluşturabilir. Ayrıca idarecilerin yönetim kadrolarını tercih etmelerindeki sebepleri incelendiğinde elde edilecek veriler de yönetim kadrolarını tercih edecek adaylara yol göstermesi bakımından büyük önem arz etmektedir. Belirtilen gerekçelerden dolayı bu araştırmanın problemini "İdarecilerin Yönetim Kadrolarını Tercih Etme Sebepleri ve Yönetici Seçimi ile İlgili Görüşlerinin İncelenmesi” oluşturmaktadır. 


\section{Araştırmanın Amacı}

Araştırma ortaöğretim kurumlarında görev yapan idarecilerin yönetim kadrolarını tercih etme sebepleri ve yönetici seçimi ile ilgili görüşleri incelemek amacıyla hazırlanmıştır. Bu genel amaç doğrultusunda aşağıdaki sorulara cevap aranmıştır:

1. Katılımcıların yönetici kadrolarını tercih etmesine ilişkin görüşleri nelerdir?

2. Katılımcıların seçiminde uygulanacak yazılı sınavı hazırlayan ve uygulayan kurum, kuruluş hakkındaki görüşleri nelerdir?

3. İdarecilerin, eğitim kurumları yöneticiliğinde başarı ölçütleri konusunda görüşleri nelerdir?

4. İdarecilerin, yönetici kadrolarındaki görevlendirmelerde, sınav ve mülakat dışında kullanılabilecek ölçütler konusunda görüşleri nelerdir?

5. Cinsiyet değişkeni açısından idarecilerin yönetim kadrolarını tercih etme sebepleri arasında bağımlılık ilişkisi var mıdır?

6. Branş ile yönetim kadrolarını tercih sebepleri (yöneticiliğin sunduğu imkânlardan kaynaklı faktörler ve kişisel özelliklerden kaynaklı faktörler) arasında bağımlılı ilişkisi var mıdır?

7. Eğitim kurumlarına yönetici seçilme şekli (sınavlı - sınavsız) ile eğitim kurumlarına atanacak yöneticiler için yapılan mülakat sınavı arasında bağımlılık ilişkisi var mıdır?

\section{Yöntem}

\section{Araştırma Modeli}

İdarecilerin yönetim kadrolarını tercih etme sebepleri ve yönetici seçimi ile ilgili görüşlerini incelenmeyi amaçlayan bu araştırma tarama modelindedir. Tarama modeli geçmişte ya da o anda var olan bir durumu var olduğu gibi betimleyen, tanımlamayı amaçlayan araştırma yaklaşımıdır. Bu modelde araştırmaya konu edinilen konuları değiştirmek, etkilemek çabası yoktur. Bu modelde temel amaç değişime neden olmadan gözlemleme yapmaktır (Karasar, 2009). Bir olayla ilişkili olma durumunun belirlenmesi ve bu durumun kestirilmesi ile ilgili araştırmalar da tarama türü araştırmalardır (Cohen, Manion ve Morrison, 2007).

\section{Evren - Örneklem}

Araştırmanın evreni 2019-2020 eğitim öğretim yılı Rize ili merkezindeki Milli Eğitim Bakanlı̆̆1na bağlı resmi 8 Mesleki ve Teknik Lise, 4 Anadolu Lisesi, 4 İmam Hatip Lisesi, 1 Fen Lisesi, 1 Sosyal Bilimler Lisesi ve 1 Güzel Sanatlar Lisesinden oluşan toplam 19 ortaöğretim okulundan 80 yöneticiyi (müdür, müdür başyardımcısı, müdür yardımc1sı) kapsamaktadır. Anket uygulamasında örnekleme yöntemine başvurulmamış ve evreninin tamamına ulaşılması hedeflenmiştir. Ancak görevli veya izinli olmaları nedeniyle 80 yöneticiden altısına uygulama yapılamamıştır. Bu nedenle araştırma evreninin \%92,5’ini (f=74) kapsamaktadır. Basit seçkisiz örnekleme yöntemiyle evrenden çekilen 18 yöneticiyle görüşme gerçekleşmiştir. Basit seçkisiz örneklemde evreni oluşturan her birim eşit seçilme olasıllı̆̆na sahiptir ve seçilen birim diğerlerinin seçilme olasılığını etkilememektedir (Kurt, 2013).

Tablo 1. Katılamcilarn Demografik Özellikeleri $(n=74)$

\begin{tabular}{|c|c|c|c|}
\hline Değişkenler & Alt Kategoriler & $f$ & $\%$ \\
\hline \multirow{2}{*}{ Cinsiyet } & Erkek & 61 & 82,4 \\
\hline & Kadin & 13 & 17,6 \\
\hline \multirow{3}{*}{ Görevi } & Müdür Yardımc1s1 & 51 & 68,9 \\
\hline & Müdür & 17 & 23 \\
\hline & Müdür Başyardımcıs1 & 6 & 8,1 \\
\hline \multirow{4}{*}{ Öğretmenlik Hizmet Süresi } & 6-10 Yil & 22 & 29,73 \\
\hline & 11-15 Yil & 19 & 25,68 \\
\hline & $1-5 Y_{1 l}$ & 12 & 16,22 \\
\hline & 21-25 Yil & 10 & 13,51 \\
\hline \multirow[t]{2}{*}{ Öğretmenlik Hizmet Süresi } & $16-20 \mathrm{Y}_{11}$ & 9 & 12,16 \\
\hline & $26 Y_{1 l}$ ve Üstü & 2 & 2,7 \\
\hline \multirow{6}{*}{ Yöneticilik Hizmet Süresi } & 1-5 Yil & 34 & 45,94 \\
\hline & $6-10 Y_{1 l}$ & 17 & 22,97 \\
\hline & $16-20 \mathrm{Y}_{11}$ & 8 & 10,81 \\
\hline & $11-15 Y_{11}$ & 5 & 6,76 \\
\hline & 21-25 Yil & 5 & 6,76 \\
\hline & 26 Yil ve Üstü & 5 & 6,76 \\
\hline \multirow{2}{*}{ Branş } & Sözel & 49 & 66,22 \\
\hline & Sayisal & 25 & 33,78 \\
\hline \multirow{2}{*}{ Eğitim Durumu } & Lisans & 62 & 83,8 \\
\hline & Yüksek Lisans & 12 & 16,2 \\
\hline
\end{tabular}


Tablo 1'de mevcut yöneticilerin cinsiyet oranlarına bakıldığında, \%17,60'1 (f=13) kadın, \%82,40'1 ( $\mathrm{f}=61)$ erkek olduğu görülmektedir. Araştırmaya katılan yöneticilerin büyük çoğunluğunun erkek olduğu görülmektedir. Mevcut yöneticilerin görev dağılımına bakıldığında, \%23’ü ( $\mathrm{f}=17)$ müdür, $\% 8,10$ ’u (f=6) müdür başyardımcisı, \%68,90’1 (f=51) müdür yardımcısı olduğu görülmektedir. Araştırmaya katılan yöneticilerin büyük çoğunluğunun müdür yardımcısı olduğu görülmektedir. Yöneticilerin öğretmenlikte geçen hizmet sürelerine bakıldığında, $\% 16,22$ 'si ( $\mathrm{f}=12$ ) 5 yll ve altı, $\% 29,73$ 'ü (f=22) 6-10 yll, \%25,68’i $(\mathrm{f}=19) 11-15$ yll, \%12,16’s1 (f=9) 16-20 yll, \%13,51’i ( $\mathrm{f}=10)$ 21-25 yll ve $\% 2,70 ’ \mathrm{i}(\mathrm{f}=2)$ ise 26 yll ve üstü olduğu görülmektedir.

Araştırmaya katılan yöneticilerin büyük çoğunluğu öğretmenlik hizmet süresinin 15 yll ve altında olduğu görülmektedir. Yöneticilerin yöneticilikte geçen hizmet sürelerine bakıldığında, \%45,94’ü (f=34) 5 yll ve alt1, \%22,97'si (f=17) 6-10 yll, \%6,76's1 (f=5) 11-15 yll, \%10,81'i (f=8) 16-20 yll, \%6,76's1 (f=5) 21-25 yll ve $\% 6,76$ 's1 (f=5) ise 26 yll ve üstü olduğu görülmektedir. Araştırmaya katılan yöneticilerin yarısına yakını yöneticilik hizmet süresinin 5 yıl ve altında olduğu görülmektedir. Mevcut yöneticilerin branş dağılımına bakıldığında, \%66,22'si (f=49) sözel branş, \%32,43’ü ( $\mathrm{f}=24)$ sayısal branş öğretmeni olduğu görülmektedir. Katılımcıların büyük çoğunluğunun sözel branş olduğu görülmektedir. Yöneticilerin eğitim durumlarına bakıldığında, \%83,80'i ( $\mathrm{f}=62$ ) lisans, \%16,20'si ( $\mathrm{f}=12)$ yüksek lisans mezunu olduğu görülmektedir. Katıllımcıların büyük çoğunluğunun lisans mezunu olduğu görülmektedir.

\section{Veri Toplama Araçları}

Araştırmada veri toplamak amacıyla, Özbilen ve Günay (2018) tarafindan hazırlanıp yayınlanmış "Öğretmenlerin Okul Yöneticiliği İstekliliğini Etkileyen Faktörlerin Belirlenmesi” başlıklı makaledeki görüşme sorularından yararlanılmıstır. Ayrıca Öztabak (2015) tarafından hazırlanıp yayınlanmış "Okul Yöneticisi Seçme Atama ve Yetiştirme Sürecine İlişkin Yönetici ve Öğretmen Görüşleri” başlıklı yüksek lisans tezinde kullanılan anket sorularından ve Vergili (2015) tarafından hazırlanıp yayınlanmış "Eğitim Kurumlarına Yönetici Seçme, Yetiştirme ve Atamaya İlişkin Okul Yöneticilerinin Görüşleri” başlıklı yüksek lisans tezinde kullanılan anket sorularından da yararlanılmıştır. Anket ve yarı yapılandırılmış görüşme formu kendisi de idareci konumda olan araştırmacı tarafından hazırlanmış ve geçerlilik ve çalışmaları ile son hâli verilmiştir. Anket ve görüşme formu sorularını kullanmak için araştırma sahiplerinden izin alınmıstır.

İdarecilerin Yönetim Kadrolarm Tercih Etme Sebepleri ve Yönetici Seçimi ile İlgili Görïslerinin İncelenmesine İlişkin Anket: $\mathrm{Bu}$ anket üç bölümden oluşmaktadır. Anketin birinci bölümünde katıllımcıların kişisel bilgilerinin alındığı altı soru yer almaktadır. İkinci bölümde kişisel faktörlerden kaynaklı ve yöneticiliğin sunduğu imkânlardan kaynaklı faktörlerin yönetim kadrolarının tercih edilmesine etkisiyle ilgili 13 Likert tipi soruya yer verilmiştir. Üçüncü bölümde ise eğitim kurumlarına yönetici seçimi ile ilgili 13 soru sorulmuştur. Anket toplam 3 bölüm ve 32 sorudan oluşmaktadır. Anketin kapsam geçerliliğine uygunluğu için üç alan uzmanından görüş alınmıştır. Dil ve yazımla ilgili eksikler de giderilmiş ankete son hali verilmiştir.

İdarecilerin Yönetim Kadrolarm Tercih Etme Sebepleri ve Yönetici Seçimi Görüsme Formu: Bu formda beş açık uçlu soru yer almaktadır. Yarı yapılandırılmış görüşme, araştırma yapılacak konu hakkında araştırmaya katılım sağlayacak kişilerden, görüşme formu kullanılarak benzer türden bilgilerin elde edilmesi amacıyla gerçekleştirilen iletişim süreci olarak ifade edilmektedir. Soruları ya da konu başlıklarını içeren görüşme formu, görüşme öncesinde hazırlanır. Görüşmenin ilerleyişine göre forma ek sorular ilave edilebilme ktedir (Şimşek, 2013). Formun oluşturulması aşamasında çalışmada aktif görev alan üniversitede çalışan üç akademisyenin görüşleri alınmışır. Hazırlanan görüşme formunun güvenirliğini sağlamak amacıyla uzmanların görüşleri alınmışır. Bu güvenilirlik hesaplaması için Miles ve Huberman'ın (1994) önerdiği güvenirlik formülü kullanılmıstır.

[Güvenirlik $=$ Görüş Birliği / (Görüss Birliği + Görüş Ayrilıği) $]$

İkisi ölçme ve değerlendirme biri Türkçe eğitimi alan uzmanından alınan görüşler doğrultusunda görüş birliği tamamen sağlanmıştır ve bu oran $\% 89$ çıkmıştır. Güvenirlilik oranının $\% 70$ ve üzeri çıkması güvenilir olduğu anlamına gelmektedir (Miles ve Huberman, 1994). Elde edilen sonuç formun güvenilir olduğunu göstermektedir.

\section{Verilerin Analizi}

Araştırmada (1-4) arasında yer alan "Katılımcıların yönetici kadrolarını tercih etmesine ilişkin görüşleri”, "Katılımcıların seçiminde uygulanacak yazılı sınavı hazırlayan ve uygulayan kurum, kuruluş 
hakkındaki görüşleri”, "İdarecilerin, eğitim kurumları yöneticiliğinde başarı ölçütleri konusunda görüşleri”, "İdarecilerin, yönetici kadrolarındaki görevlendirmelerde, sınav ve mülakat dışında kullanılabilecek ölçütler konusunda görüşleri” belirlenirken frekans (f) ve yüzde (\%) tabloları oluşturulmuştur. Katıllımcıların görüşleri yazılı olarak kayıt altına alınmıştır.

Araştırmada (5-7) arasında yer alan "Cinsiyet değişkeni açısından idarecilerin yönetim kadrolarını tercih etme sebepleri (Yöneticiliğin sunduğu imkânlardan kaynaklı faktörler ve kişisel özelliklerden kaynaklı faktörler) arasında bağımlılık ilişkisi", "Branş ile yönetim kadrolarını tercih sebepleri (yöneticiliğin sunduğu imkânlardan kaynaklı faktörler ve kişisel özelliklerden kaynaklı faktörler) arasında bağımlılık ilişkisi", "Eğitim kurumlarına yönetici seçilme şekli (sınavlı - sınavsız) ile eğitim kurumlarına atanacak yöneticiler için yapılan mülakat sınavı arasında bağımlılık ilişkisi” sorularının analizinde Ki-Kare Testi kullanılmıştır. Ki-Kare Testi iki ya da daha çok kategoriye sahip iki değişken arasında bağımlllık olup olmamasını araştırmak için kullanılmaktadır (Bayram, 2017). Yapılan görüşmeler sonucunda yöneticilerin sorulara verdiği cevapların sıklı̆̆ına göre, bir sınıflama yapılmıştır. Bu sınıflamaya bağlı olarak kategoriler oluşturularak analiz edilip tablolara aktarılmış ve katıllımcıların görüşleriyle desteklenmiştir.

\section{Bulgular ve Yorumlar}

Araştırmanın bu bölümünde anket ve görüşme formundan oluşan ölçme araçları uygulanarak katılımcılardan elde edilen verilerin analizi sonucundaki bulgular ve araştırma bulgularına ilişkin yorumlar yer almaktadır.

\section{Katılımcıların Yönetici Kadrolanın Tercih Etmesine İlişkin Görüşlerine İlişkin Bulgular}

Yönetici kadrolarının tercih edilmesinde, kişisel özellikler ve yöneticiliğin sunduğu imkânlardan kaynaklı faktörlerin ne derece etkili olduğuna ilişkin katılımcıların görüşleri "Hiç katılmıyorum-Tamamen katılıyorum" aralığında frekans ve yüzde olarak aşağıdaki tabloda verilmiştir. Tablo 2 incelendiğinde mevcut yöneticilerin yönetici kadrolarını tercih etmelerinde eğitimin kalitesini artırma isteğine bakıldığında \%40,50'sinin ( $\mathrm{f}=30$ ) katıllımcıların yarısına yakını tamamen katılıyorum görüşünde olduğu görülmektedir. Mevcut yöneticilerin yönetici kadrolarını tercih etmelerinde demokratik bir okul kültürü oluşturma isteğine bakıldığında \%47,30'unun ( $\mathrm{f}=35)$ katılımcıların yarısına yakını tamamen katılıyorum görüşündedir.

Tablo 2. Katılmmolarn Yönetici Kadrolarm Tercih Etme İstatistikleri

\begin{tabular}{|c|c|c|c|c|c|c|c|c|c|c|}
\hline & \multicolumn{2}{|c|}{$\begin{array}{c}\text { Hiç } \\
\text { Katılmiyorum }\end{array}$} & \multicolumn{2}{|c|}{ Katılmiyorum } & \multicolumn{2}{|c|}{$\begin{array}{l}\text { Orta Derecede } \\
\text { Katılyyorum }\end{array}$} & \multicolumn{2}{|c|}{ Katılyyorum } & \multicolumn{2}{|c|}{$\begin{array}{c}\text { Tamamen } \\
\text { Kattlyorum }\end{array}$} \\
\hline & $f$ & $\%$ & $f$ & $\%$ & $f$ & $\%$ & $f$ & $\%$ & $f$ & $\%$ \\
\hline Eğitimin kalitesini artırma isteği & 1 & 1,4 & 5 & 6,8 & 11 & 15 & 27 & 37 & 30 & 41 \\
\hline $\begin{array}{l}\text { Demokratik bir okul kültürü oluşturma } \\
\text { isteği }\end{array}$ & 1 & 1,4 & 2 & 2,7 & 11 & 15 & 25 & 34 & 35 & 47 \\
\hline Öğrenme ve kendini geliştirme isteği & 1 & 1,4 & 2 & 2,7 & 12 & 16 & 28 & 38 & 31 & 42 \\
\hline Yöneticilik tecrübesinin olmas1 & 1 & 1,4 & 5 & 6,8 & 12 & 16 & 32 & 43 & 24 & 32 \\
\hline İletişim becerilerimin güçlü olması & 1 & 1,4 & 8 & 11 & 5 & 6,8 & 33 & 45 & 27 & 37 \\
\hline Liderlik özelliklerine sahip olunması & 1 & 1,4 & 9 & 12 & 5 & 6,8 & 33 & 45 & 26 & 35 \\
\hline Mesleki doyumu sağlaması & 0 & 0 & 19 & 26 & 23 & 31 & 24 & 32 & 8 & 11 \\
\hline $\begin{array}{l}\text { Yeni projeler üretme ve uygulayabilme } \\
\text { imkânı }\end{array}$ & 2 & 2,7 & 7 & 9,5 & 16 & 22 & 33 & 45 & 16 & 22 \\
\hline Yöneticilerin ders yükünün az olmas1 & 13 & 18 & 18 & 24 & 18 & 24 & 21 & 28 & 4 & 5,4 \\
\hline $\begin{array}{l}\text { Öğretmenlerin mesleki tükenmişlik } \\
\text { yaşaması }\end{array}$ & 14 & 19 & 19 & 26 & 23 & 31 & 13 & 18 & 5 & 6,8 \\
\hline Ek ders ücretlerinin fazla olması & 16 & 22 & 27 & 37 & 19 & 26 & 10 & 14 & 2 & 2,7 \\
\hline Çalışma alanının daha kapsamlı olması & 1 & 1,4 & 12 & 16 & 17 & 23 & 32 & 43 & 12 & 16 \\
\hline $\begin{array}{l}\text { Yöneticilikte kariyer basamaklarının } \\
\text { olması }\end{array}$ & 7 & 9,5 & 19 & 26 & 17 & 23 & 21 & 28 & 10 & 14 \\
\hline
\end{tabular}

Yöneticilerin yönetici kadrolarını tercih etmelerinde öğrenme ve kendini geliştirme isteğine bakıldığında da \%41,90'ının $\quad(\mathrm{f}=31)$ katılımcıların yarısına yakını tamamen katıliyorum görüşündedir. Mevcut yöneticilerin yönetici kadrolarını tercih etmelerinde yöneticilik tecrübesinin olmasına bakıldığında \% 43,20'sinin ( $\mathrm{f}=32$ ) katılımcıların yarısına yakını katılıyorum görüşündedir.

Yönetici kadrolarını tercih etmelerinde iletişim becerilerimin güçlü olmasına bakıldığında \%44,60’ının ( $\mathrm{f}=33)$ katılımcıların yarısına yakını katılıyorum görüşündedir. Yönetici kadrolarını tercih etmelerinde liderlik özelliklerine sahip olma durumuna bakıldığında \%44,60'ının ( $\mathrm{f}=33$ ) katılımciların yarısına yakını katıllyorum görüşündedir. Yönetici kadrolarını tercih etmelerinde öğretmenlikte mesleki doyumun 
sağlanmasına bakıldığında katılımcıların görüşleri değişmekle birlikte \%32,40’inın (f=24) katıllyorum görüşünde toplanıldığı görülmektedir. Yönetici kadrolarını tercih etmelerinde yeni projeler üretme ve uygulayabilme imkânına bakıldığında yine \%44,60'ının ( $\mathrm{f}=33$ ) katılımcıların yarısına yakını katılıyorum görüşündedir. Yönetici kadrolarını tercih etmelerinde yöneticilerin ders yükünün az olması durumuna bakıldığında katılımcıların görüşleri değişmekle birlikte $\% 28,40^{\prime} ı n ı n ~(f=21)$ katılıyorum görüşünde toplanıldığ1 görülmektedir. Yönetici kadrolarını tercih etmelerinde öğretmenlerin mesleki tükenmişlik yaşama durumuna bakıldığında katılımciların \%31,10’unun $(\mathrm{f}=23)$ orta derecede katıldığ1 görülmektedir. Yönetici kadrolarını tercih etmelerinde ek ders ücretlerinin fazla olması durumuna bakıldığında katılımcıların \%36,50'sinin ( $\mathrm{f}=27)$ katılmıorum görüşündedir. Yönetici kadrolarını tercih etmelerinde çalışma alanının daha kapsamlı olmasına bakıldığında \%43,20'sinin ( $\mathrm{f}=32$ ) katıllyorum görüşünde olduğu görülmektedir. Yönetici kadrolarını tercih etmelerinde yöneticilikte kariyer basamaklarının olması durumuna bakıldığında katılımciların \%28,40’ının ( $\mathrm{f}=21$ ) katıllyorum görüşünde olduğu görülmektedir.

\section{Katılımcıların Seçiminde Uygulanacak Yazılı Sinavı Hazırlayan ve Uygulayan Kurum, Kuruluş Hakkındaki Görüşlerine Illişkin Bulgular}

Tablo 3. Katıllmcılarn Yönetici Seçiminde Uygulanacak Yažl Sinav Hažrlayan ve Uygulayan Kurum, Kurulus ile İgili İstatistikler

\begin{tabular}{lcc}
\hline Yönetici seçim sınavı hazırlayan ve uygulayan kurum kuruluş & $\boldsymbol{f}$ & $\boldsymbol{\%}$ \\
\hline ÖSYM hazırlamalı ve uygulamalıdır. & 28 & 62,22 \\
MEB hazırlamalı ve merkezi sistemle uygulamalıdır. & 13 & 28,90 \\
Öğretim üyelerinden oluşturulacak komisyonca yapılmalıdır. & 2 & 4,44 \\
Valilikler, kendi koşullarını belirleyerek hazırlamalı ve uygulamalıdır. & 1 & 2,22 \\
Başka & 1 & 2,22 \\
\hline Toplam & 45 & 100 \\
\hline
\end{tabular}

Tablo 3 incelendiğinde eğitim kurumlarına yönetici seçiminde sınav uygulanması gerektiği görüşünde olan mevcut yöneticilerden, yönetici seçiminde uygulanacak yazılı sınavı hazırlayan ve uygulayan kurum, kuruluşlar hakkında \%62,22'sinin ( $\mathrm{f}=28$ ) ÖSYM hazırlamalı ve uygulamalıdır görüşündedir. \%28,90'nnın ( $\mathrm{f}=13)$ MEB hazırlamalı ve merkezi sistemle uygulamalıdır, $\% 2,22$ 'sinin $(\mathrm{f}=1)$ valilikler kendi koşullarını belirleyerek hazırlamalı ve uygulamalıdır, $\% 4,44$ 'ünün $(\mathrm{f}=2$ ) öğretim üyelerinden oluşturulacak komisyonca yapılmalıdır, \%2,22'sinn ( $\mathrm{f}=1)$ başka seçeneği görüşünde olduğu görülmektedir. Katılımcıların yarıdan fazlası eğitim kurumlarına yönetici seçme sınavının ÖSYM tarafından hazırlaması ve uygulaması gerektiği görüşündedir. Yeloğlu (2008) tarafindan İstanbul'da yapılan benzer bir çalışmada eğitim kurumlarına yönetici seçiminde sınav uygulanması gerektiği görüşünde olan katllımcıların, yönetici seçiminde uygulanacak yazılı sinavı hazırlayan ve uygulayan kurum, kuruluşlar hakkında \%53,10’u ÖSYM tarafindan hazırlanması ve uygulanması gerektiği görüşündedir.

Vergili (2015) benzer bir çalş̧mada da eğitim kurumlarına yönetici seçiminde sınav uygulanması gerektiği görüşünde olan katılımcıların, yönetici seçiminde uygulanacak yazılı sınavı hazırlayan ve uygulayan kurum, kuruluşlar hakkında \%43,50'si ÖSYM tarafindan hazırlanması ve uygulanması gerektiği görüşündedir. Elde edilen bulgular Yeloğlu ve Vergili tarafından yapılan benzer çalışmadaki yönetici seçme sınavı ÖSYM tarafindan hazırlanmalı ve uygulanmalı seçeneğini destelemekle birlikte yönetici seçme sınavı MEB tarından hazırlanmalı ve merkezi sistemle uygulanmalıdır seçeneğini de gündeme getirmiştir.

\section{İdarecilerin, Eğitim Kurumları Yöneticiliğinde Başarı Ölçütleri Konusunda Görüşlerine İlighkin Bulgular}

Bu alt amaca ilişkin katılımcılarla yapılan görüşme sonrasında elde edilen verilere dayalı olarak aşağıda (f) ve (\%) tablosu oluşturulmuştur. Katıllımcıların görüşleri transkript edilmiştir. Bulgular ayrıca katılımcıların görüşleriyle desteklenmiştir.

Tablo 4. Katıllmcularn Eğitim Kurumlar Yöneticiliüinde Bașar Ölçütleri İstatistikleri

\begin{tabular}{lc} 
Ë̆itim kurumları yöneticiliğinde başarı ölçütleri & $\boldsymbol{f}$ \\
\hline Kurumsal kimliğin kurum kültürünün oluşması, kurum içi mutluluk, güvenli ve huzurlu çalsşma ortamının \\
oluşturulması \\
Öğrenci, veli, personel memnuniyeti
\end{tabular}


Tablo 4 incelendiğinde katılımcıların, eğitim kurumları yöneticiliğinde başarı ölçütleri hakkındaki görülerine bakıldığında, \%38,89’unun (f=7) kurumsal kimliğin kurum kültürünün oluşması, kurum içi mutluluk, güvenli ve huzurlu çalışma ortamının oluşturulması gerektiği, \%22,22'sinin (f=4) akademik başarı, gerçekleştirilen kültürel etkinlikler olduğu, \%38,89’unun (f=7) Öğrenci, veli, personel memnuniyeti olduğu görüşündedir. Aşağıda bazı katılımcılara ait verilen görüşler bu durumu açıklamaktadır.

K3: "Bir okulda kurumsal kimlik oluşturulmuşsa, kurum içi mutluluk sağlanmış ve akademik başarı yükseltilmişse okul yöneticisinin başarılı olduğu söylenebilir. Şunu da belirtmek gerekir kurumdaki başarı sadece öğrenci, öğretmen performansina bağlı değildir bazen de iyi iletişimdir."

K17: “Okul yöneticisinin başarılı kabul edilmesi okul paydaşları olan öğrenci, veli ve personelin yöneticiliğinden ne derece memnun olduğuyla ilgilidir. Bütün bu öğelerden bir ya da birkaçının memnuiyetsizliği büyük bir soruna dönüşebilir."

Katılımcılardan elde edilen görüşler doğrultusunda eğitim kurumlanı yöneticiliğinde başarı ölçütleri içinde "Kurumsal kimliğin kurum kültürünün oluşması, kurum içi mutluluk, güvenli ve huzurlu çalışma ortamının oluşturulması, öğrenci, veli, personel memnuniyeti” ölçütlerinin daha fazla önemsendiği görülmektedir.

\section{Ídarecilerin, Yönetici Kadrolarında Görevlendirme S1nav ve Mülakat Dişında Kullanılacak Ölçütler Konusunda Görüşleri İlişkin Bulgular}

Bu alt amaca ilişkin katılımcılarla yapılan görüşme sonrasında elde edilen verilere dayalı olarak aşağıda (f) ve (\%) tablosu oluşturulmuştur. Katılımcıların görüşleri transkript edilmiştir. Bulgular ayrıca katılımcıların görüşleriyle desteklenmiştir.

Tablo 5. Yönetici Atama Değerlendirmelerinde Sınav ve Mülakat Dışında Kullamlabilecek Ölçüt İstatistikleri

\begin{tabular}{lc}
\hline Eğitim kurumlarına yönetici atama değerlendirmelerinde sınav ve mülakat dişında kullanılabilecek ölçütler & $\boldsymbol{f}$ \\
\hline Hizmet süresi & 7 \\
Ulusal, uluslararası projeler, toplum hizmeti çalışmalarına katılım sağlanması & 4 \\
Hizmetiçi eğitimlere katılım sağlanması & 4 \\
Yüksek lisans & 3 \\
\hline Toplam & 18 \\
\hline
\end{tabular}

Tablo 5 incelendiğinde katılımcıların, eğitim kurumlarına yönetici atama değerlendirmelerinde sınav ve mülakat dişında kullanılabilecek ölçütler hakkında, \%38,89'unun ( $f=7$ ) hizmet süresi, \%16,67'sinin ( $f=3$ ) yüksek lisans, \%22,22'sinin $(\mathrm{f}=4)$ ulusal ve uluslararası projeler, toplum hizmeti çalışmalarına katılım sağlanması, \%22,22’sinin ( $\mathrm{f}=4$ ) hizmetiçi eğitimlere katılım sağlanması olduğu görüşündedir. Aşağıda bazı katılımcılara ait görüşler bu durumu açıklamaktadır.

K1: "Hizmet süresinden alınan puan yetersizdir. Puan değeri yükseltilmelidir. Hizmet süresinin fazla oluşu tecrübenin arttı̆̆ını gösterir. Yöneticilikte tecrübe önemlidir.’"

K6: "Toplum hizmet çalışmalarında etkin görev üstlenilmesi yönetici seçiminde olumlu etki sağlamalıdır."

K10: "Hizmet süresi ve yöneticilik alanında katıldığı hizmetiçi eğitim sayısı yönetici seçiminde pozitif bir etki oluşturmalıdır."

Katılımcılardan elde edilen görüşler doğrultusunda eğitim kurumlarına yönetici atama değerlendirmelerinde sınav ve mülakat dışında kullanılabilecek ölçütler içinde "Hizmet süresi” ölçütünün daha fazla önemsendiği görülmektedir.

Cinsiyet Değişkeni ile İdarecilerin Yönetim Kadrolanını Tercih Etme Sebepleri (Yöneticiliğin Sunduğu İmkânlardan Kaynaklı Faktörler ve Kişisel Özelliklerden Kaynaklı Faktörler) Arasında Bağımlılık Illişkisine IIlişkin Bulgular

Bu alt amacın yanıtında kategorik veriler üzerinden uyum analizi yapıldığı için non-parametrik bir test olan Ki-Kare Uyum Testi kullanılmıştır. 
Tablo 6. Cinsiyet İle Yönetici Kadrolarm Tercih Sebepleri Arasındaki Ki-Kare Bağmmsı̨̨lle. Testi

\begin{tabular}{lcccc}
\hline \multicolumn{4}{c}{ Okul Yöneticilerinin Yönetici Kadrolarını Tercih Etmelerinde Etkili } \\
Olan Faktörler
\end{tabular}

Tablo 6'da katılımcilardan ( $\mathrm{f}=61)$ erkek, $(\mathrm{f}=13)$ kadındır. Yöneticiliğin sunduğu imkânlardan kaynaklı faktörler açısından ( $\mathrm{f}=10$ ) erkek, ( $\mathrm{f}=5)$ kadın; kişisel özelliklerden kaynaklı faktörler açısından ( $\mathrm{f}=51$ ) erkek, $(\mathrm{f}=8)$ kadın olduğu görülmektedir. Cinsiyet değişkeni açısından idarecilerin yönetim kadrolarını tercih etme sebepleri (Yöneticiliğin sunduğu imkânlardan kaynaklı faktörler ve kişisel özelliklerden kaynaklı faktörler) için yapılan analiz sonucunda bağımlılık ilişsisi (uyum) görülmemiştir. Ki-Kare Testinde en küçük teorik değer dikkate alındığında Fisher'sExact test sonucunu kullanılması gerekmektedir ([p>.05; $\mathrm{p}=0.083]$. Bu sonuç .05 manidarlık düzeyinin üzerindedir. Bu sebeple kadın ya da erkek olma durumunun tercih sebepleriyle bir bağımlılık ilişkisi bulunmadığı görülmektedir.

Branş ile Yönetim Kadrolarını Tercih Sebepleri (Yöneticiliğin Sunduğu İmkânlardan Kaynaklı Faktörler ve Kişisel Özelliklerden Kaynaklı Faktörler) Arasında Bağımlılık IIlişkisine İliskin Bulgular

$\mathrm{Bu}$ alt amacın yanıtında Ki-Kare Uyum Testi kullanılmıştır.

Tablo 7. Branş İle Yönetici Kadrolarm Tercih Sebepleri Arasindaki Ki-Kare Bağımsıฉ̨lle Testi

\begin{tabular}{|c|c|c|c|c|c|}
\hline \multicolumn{6}{|c|}{$\begin{array}{c}\text { Okul Yöneticilerinin Yönetici Kadrolarını Tercih Etmelerinde Etkili } \\
\text { Olan Faktörler }\end{array}$} \\
\hline Branş & $\begin{array}{c}\text { Yöneticiliğin Sunduğu } \\
\text { İmkânlardan Kaynaklı Faktörler }\end{array}$ & $\begin{array}{l}\text { Kişisel Özelliklerden } \\
\text { Faktörler }\end{array}$ & Kaynakl1 & Toplam & $p$ \\
\hline Sayisal & 5 & 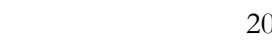 & & 25 & \\
\hline Sözel & 14 & 35 & & 49 & \\
\hline Fisher's Exact Test & & & & & 0,036 \\
\hline Toplam & 15 & 59 & & 74 & \\
\hline
\end{tabular}

Tablo 7'de yöneticiliğin sunduğu imkânlardan kaynaklı faktörler açısından ( $\mathrm{f}=5$ ) sayısal, (f=14) sözel; kişisel özelliklerden kaynaklı faktörler açısından ( $\mathrm{f}=20)$ sayısal, $(\mathrm{f}=35)$ sözel olduğu görülmektedir. Branş ile yönetim kadrolarını tercih sebepleri (yöneticiliğin sunduğu imkânlardan kaynaklı faktörler ve kişisel özelliklerden kaynaklı faktörler) arasında .05 düzeyinde branşla yöneticiliğin sunduğu imkanlar ile kişisel özellikleri arasında bağımlılık ilişkisi bulunmaktadır [p<.05; $\mathrm{p}=.036]$. Katılımcıların \%66'sının sözel branş öğretmeni olduğu görülmektedir.

Eğitim Kurumlarına Yönetici Seçilme Şekli (Sınavl1-Sınavsız) ile Eğitim Kurumlarına Atanacak Yöneticiler için Yapılan Mülakat Sınavı Arasında Bağımlılık Illişkisine İlişkin Bulgular

$\mathrm{Bu}$ alt amacın yanıtında Ki-Kare Uyum Testi kullanılmıştır. Tablo 8'de mülakat sınavı yapılması açısından ( $\mathrm{f}=23$ ) sinavla, $(\mathrm{f}=15)$ sinavsız; mülakat sınavı yapılmaması açısından $(\mathrm{f}=22)$ sinavla, $(\mathrm{f}=14)$ sınavsız olduğu görülmektedir.

Tablo 8. Yönetici Seçilme Şekli İle Mülakat Sinavn Arasındaki Ki-Kare Bağımsı̨̆lk Testi

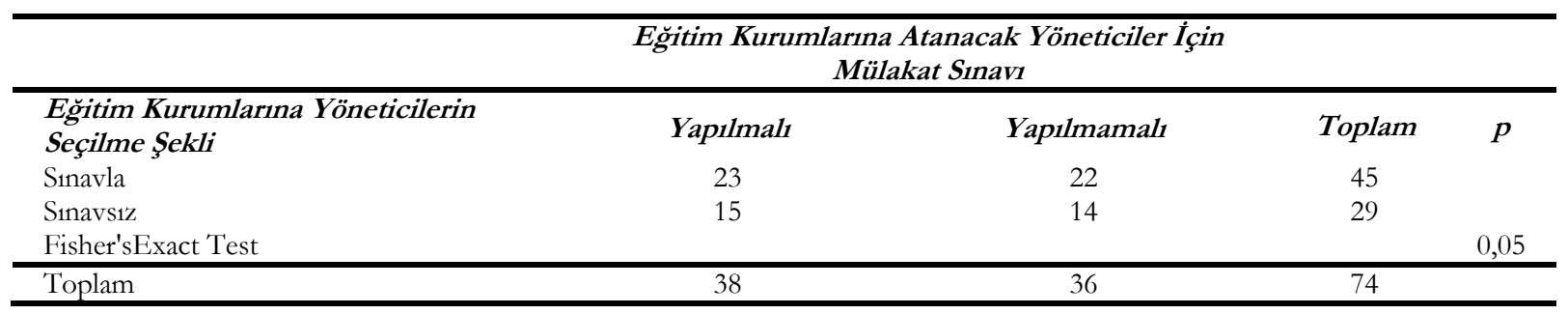


Eğitim kurumlarına yönetici seçilme şekli (sınavlı - sınavsız) ile eğitim kurumlarına görevlendirilecek yöneticiler için yapılacak mülakat sınavı arasında bağımlllı ilişkisi olduğu görülmektedir $[\mathrm{p}<.05 ; \mathrm{p}=$ .05]. Daha önce literatürde benzer bir sorgulama yapılmadığı görülmüştür. Bu sebeple bu bulgu ayrıca çalışmada önem göstermektedir.

\section{Sonuç ve Öneriler}

Bu bölümde, araştırmanın bulgularına dayalı olarak çıkarılan sonuçlar ve bu sonuçlara göre geliştirilen önerilere yer verilmiştir.

\section{Sonuçlar}

Araştırmanın bulgularına dayalı sonuçlar, maddeler hâlinde aşağıda sıralanmıştır:

1. Mevcut yöneticilerin yönetici kadrolarını tercih etmelerinde eğitimin kalitesini artırma, demokratik bir okul kültürü oluşturma, kendini geliştirme yeni projeler üretme ve uygulayabilme isteğinin tercih sebepleri arasında olduğu görülmektedir.

2. Yönetici seçiminde yazılı sınavı ÖSYM hazırlamalı ve uygulamalıdır görüşü ve MEB hazırlamalı ve merkezi sistemle uygulamalıdır görüşü ortaya çıkmaktadır.

3. Eğitim kurumları yöneticiliğinde başarı ölçütleri hakkındaki görüşler kurumsal kimliğin oluşması gerekliliği, kurum içi mutluluk, güvenli ve huzurlu çalışma ortamının oluşturulması, gerçekleştirilen kültürel etkinliklerin ve öğrenci, veli, personel memnuniyetinin bütünü şeklinde ortaya çıkmaktadır.

4. Katılımcılar, sınav ve mülakat dışında yönetici değerlendirmede başta hizmet süresi olmak üzere, ulusal, uluslararası projeler, toplum hizmet etkinliklerine ve hizmetiçi eğitimlere katılımının sağlanması şeklinde ölçütler kullanılması gerektiğini belirtmektedir.

5. Cinsiyet ile yönetici kadrolarının tercih sebepleri arasında bir bağımlılık ilişkisine rastlanmamıştır.

6. Branş ile yönetici kadrolarının tercih sebepleri arasında bir bağımlılık ilişkisi bulunmuştur.

7. Yönetici seçilme şekli ile mülakat sınavı arasında bir bağımlılık ilişkisi bulunmuştur.

\section{Öneriler}

Bu bölümde, araştırmanın bulgularına dayalı olarak çıkarılan sonuçlara göre geliştirilen öneriler verilmiştir.

1. Eğitimin kalitesini artırma, demokratik bir okul kültürü oluşturma vb. gibi yöneticiliği tercih etme sebeplerinin varlığı dikkate alınarak eğitimcilere amaçlarına ulaşmaları yolunda yüksek lisans ve doktora gibi lisansüstü programlara girebilme imkânı da verilebilir.

2. Yönetici seçiminde, alan uzmanı öğretim üyelerinden oluşturulacak komisyonca hazırlanan sorular MEB ortaklığı ile önceden belirlenen puanlama ölçütleri dikkate alınarak ÖSYM tarafindan merkezi bir sınavla uygulanabilir. Valilikler de sinav kontrol mekanizması olarak yer alabilir.

3. Yöneticilerin sahip olması gereken başarı ölçütlerinde il genelinde tüm eğitim-öğretim kademelerindeki yöneticilerin görüşleri alınarak belirlenebilir. Belirlenen bu özellikler yönetici seçiminde, görevlendirmelerinde ölçüt olarak yer alabilir. Böylelikle kurum içi daha adil, profesyonel, başarılı bir kurum kültürünün de gelişmesine firsat sunabilir. Bölgesel ya da ulusal düzeyde araştırmalar yapılabilir ve araştırmanın problemi temel alınarak evren genişletilebilir. Başarı ölçütleri somut olarak ortaya konulabilir. Yönetici başarı durumu böylece kişinin inisiyatifinden arınık şekilde belirlenebilir.

4. Hizmet süresinden alınan puan değeri yükseltilebilir, sivil toplum kuruluşları, toplum hizmet çalışmalarında etkin görev alımlarında ve hizmetiçi eğitim sayısı yönetici seçiminde birer ölçüt olarak kullanılabilir. Eğitim yöneticileri göreve başlamadan önce Milli Ĕ̆itim Bakanlığ1 ve üniversiteler işbirliği içerisinde, alanında uzman kişiler tarafindan eğitim yönetimi alanında zorunlu hizmetiçi eğitim uygulanabilir ve eğitimi sonunda sınav yapılarak başarılı olanlar yönetici adayı olarak seçilebilir.

5. Yönetici kadrolarının tercih sebepleri cinsiyet dışında "yaşanılan bölge, yaş, kıdem, branş ve medeni durum" değişkenlerinin herhangi biriyle sorgulanabilir.

6. Branşlarda sözel alanda görev yapan öğretmenlerin neden yönetim kadrolarını daha çok tercih ettiklerinin sorgulamas1 cinsiyet, ek ders ücretlendirmesi, mesleki doyum, mesleki kariyer gibi değişkenlerden herhangi biriyle tekrar sorgulanabilir. 
7. Eğitim kurumlarına yönetici seçilme şeklinin sınavlı - sınavsız olma durumu ile eğitim kurumlarına görevlendirilecek yöneticiler için yapılan mülakat sınavı arasında ilişki olması sebebiyle mülakat sınavının ve yazılı sınavın yeniden görevlendirmelerde uygulanması önerilebilir. Eğitim kurumlarına atanacak yöneticiler için yapılacak mülakat sınavı ile ilgili görüşler cinsiyete, kıdeme, medeni duruma, yaşanılan bölgeye vb. değişkenlerden biri ile tekrar daha büyük yönetici örnekleminde incelenebilir.

\section{Belirlenen Alt Amaçlar Dışındaki Öneriler}

1. Eğitim kurumlarına yönetici görevlendirmelerinde yazılı sınav $\% 50$, mülakat sinav1 $\% 25$ ve yönetici değerlendirme formu \%25 etkili olmalıdır. Sınav tarafsız olarak düşünülen ÖSYM tarafından hazırlanıp uygulanmaya devam edilmelidir. Mülakat sınavının tarafsızlığı sağlanmalı, objektif kriterler belirlenmeli, üniversite ve bakanlık ortaklığıla oluşturulacak komisyonlar tarafindan şeffaf şekilde yürütülmelidir. Yönetici değerlendirme formunda somut ölçütlere yer verilmelidir. Bu ölçütler belirlenirken yöneticilerin çoğunluğunun mutabık kalması önemlidir.

2. Eğitim yöneticileri göreve başlamadan önce eğitim yönetimi alanında hizmetiçi eğitime alınmalı ya da eğitim yönetimi alanında yüksek lisans kriteri aranmalıdır. Hizmetici eğitimler bakanlık ve üniversiteler işbirliği içerisinde, alanında uzman kişiler tarafından verilmelidir. Bu eğitim sonunda sınav yapılarak başarılı olanlar seçilmelidir. Seçilen yönetici adayları tecrübeli, başarll, örnek çalışmalar gerçekleştiren eğitim kurumu yöneticilerinin yanında uygulamalı olarak eğitim alabilmesi için staj çalısması gerçekleştirmelidir. Uygulamalı staj eğitimini tamamlayanlar ilk olarak öğrenci sayısının az olduğu okullarda göreve başlamalı ve başarılı olmaları durumunda öğrenci sayısının daha fazla olduğu okullara görevlendirmeleri gerçekleşmelidir. Okul müdürleri bu sınavlarda başarılı olan müdür yardımcıları arasından seçim yapma hakkı tanınmalıdır.

3. İdarecilerin belirlenen somut ölçütlere göre başarı durumu, öğrenci, veli ve öğretmen memnuniyeti de dikkate alınarak görev süresi dört yıl daha uzatılabilmelidir. İdarecilik görev süreci içerisinde belirli aralıklar hizmetiçi eğitimler gerçekleştirmelidir. Okul yöneticiliği bir meslek olarak tanımlanmalı tüm tarafların görüşleri, iyi bir şekilde değerlendirilerek sürekli değişikliklerden kaynaklanan mağduriyetleri de önlemek adına yönetmelik yerine yasa ile profesyonelleştirmelidir.

\section{Etik Beyan}

“'̇darecilerin Yönetim Kadrolarm Tercih Etme Sebepleri ve Yönetici Seşimi ile İlgili Görïslerinin Incelenmesi” başlıklı çalışmanın yazım sürecinde bilimsel, etik ve alıntı kurallarına uyulmuş; toplanan veriler üzerinde herhangi bir tahrifat yapılmamış ve bu çalışma herhangi başka bir akademik yayın ortamına değerlendirme için gönderilmemiştir. Bu araştırmanın verileri 01.01.2020 tarihinden önce toplandığı için etik kurul kararı zorunluluğu taşımamaktadır.

\section{Not}

"İdarecilerin Yönetim Kadrolarm Tercih Etme Sebepleri ve Yönetici Seçimi İle İlgili Görüslerinin İncelenmesi” başlıklı çalışma Recep Tayyip Erdoğan Üniversitesi Sosyal Bilimler Enstitüsü Eğitim Yönetimi Teftişi ve Planlama Bölümü yüksek lisans öğrencisi İlhan PEÇE tarafindan Dr. Öğr. Üyesi Fazilet TAŞDEMIR danışmanlığında 11.05.2020 tarihinde video konferans uygulamasıyla tez savunmasında yükesek lisans teri olarak sunulmuş ve başarılı bulunmuştur.

\section{Kaynakça}

Açıkalın, A. (1998). Toplumsal, kurumsal ve teknik yönleriyle okul yöneticiliği (4. Baskı). Ankara: Pegem Akademi Yayınları. Balc1, A. (1993). Etkili okul kuram uygulama ve araştırma. Ankara: Ankara Üniversitesi Yayınları.

Bayram, N. (2017). Sosyal bilimlerde spss ile veri analizi (6. Baskı). Bursa: Ezgi Yayınevi.

Burasalıŏlu, Z. (2002). Okul yönetiminde yeni yapı ve davramıs (12. Baskı). Ankara: Pegem Akademi Yayınları. Burasalıoğlu, Z. (2011). Okul yönetiminde yeni yapı ve davranış (16. Baskı). Ankara: Pegem Akademi Yayınları.

Cemaloğlu, N. (2005). Türkiye'de okul yöneticisi yetiştirme ve istihdamı: Varolan durum, gelecekteki olası gelişmeler ve sorunlar. Gaz̧i Ë̆itim Fakültesi Dergisi, 2(25), 249-274. Erişim adresi: http://www.gefad.gazi.edu.tr/tr/pub/

Cohen, L., Manion, L. ve Morrison, K. (2007). Research methods in education. London and New york: Routledge.

Çelik, V. (2012). Okul kültürü ve yönetimi (5. Baskı). Ankara: Pegem Akademi Yayınları.

Drucker, P. F. (1974). Management. London: Heinemann.

Erdoğan, İ. (2006). Okul yöneticilerinin genel özellikleri ve yöneticilik tutumlarıla ilgili bir araştırma. Hasan Ali Yücel Eğitim Fakültesi Dergisi, 3(1), 03-118. Erişim adresi: https://hayefjournal.org/Content/files/ 
Eren, M. A. (1991). Türk eğitim sistemi yönetim teşkilatındaki yenileşmeler ve yönetici yetiştirme politikasımm incelenmesi (Yüksek Lisans tezi). Selçuk Üniversitesi Sosyal Bilimler Enstitüsü, Konya.

Gümüşeli, A. İ. (2001). Çağdaş okul müdürünün liderlik alanlar1. Kuram ve Uygulamada Eğitim Yönetimi Dergisi, 7(28), 348-531. Erişim adresi: http://www.kuey.net/index.php/kuey/article/view/

Günay,G. ve Özbilen,F.M.(2018)). Öğretmenlerin okul yöneticiliği istekliliğini etkileyen faktörlerin belirlenmesi. Turkish Studies,13(19),1331-1344. Erişim adresi: https://www.academia.edu/37605366/

Kalkandelen, A. H. (1985). Yöneticilerin yetiştirilmesi ve geliştirilmesi. Amme İdaresi Dergisi, 18(2), 83-112. Erişim adresi: http://iibf.erciyes.edu.tr/kutuphane/petas/petas.php

Karasar, N. (2009). Bilimsel araştırma yöntemleri (20. Baskı). Ankara: Nobel Yayınları.

Kaya, Y. K. (1986). Eg̈itim yönetimi, kuram ve Türkiye 'deki uygulama (3. Baskı). Ankara: Bilim Yayıncllı.

Kaya, Y. K. (1989). Insan yetiştirme düzenimize yeni bir bakış. Ankara: Bilim Yayıncılık.

Korkmaz, M. (2005). Okul yöneticilerinin yetiştirilmesi: Sorunlar - çözümler ve öneriler. Gą̧i Eğitim Fakültesi Dergisi, 3(25), 237-252. Erişim adresi: http://www.gefad.gazi.edu.tr/tr/download/article-file/77239

Kurt, A. A. (2013). Sosyal bilimlerde araştırma yöntemleri. Eskişehir: Anadolu Üniversitesi Yayınları.

MEB (1993).14. Milli Eğitim Şurası Hą̧rlık Dokümanı. Erişim adresi: http://ttkb.meb.gov.tr/meb_iys_dosyalar/2017 _09/2916540_14_sura.pdf

Memduhoğlu, H. B. (2007). Türk eğitim sisteminde okulların yönetimi ve okul yöneticilerinin sorunsalı. Milli Ĕ̈itim Dergisi, 176. Erişim adresi: http://dhgm.meb.gov.tr/yayimlar/dergiler/Milli_Egitim_Dergisi/176.pdf

Miles, M. B. ve Huberman, A. M. (1994). Qualitative data analysis : an expanded sourcebook. (2nd Edition). California: SAGE Publications.

Okçu, V. (2011). Türkiye'de okul yöneticilerinin yetiştirilmesi ve atanmasına ilişkin mevcut durum, beklentiler ve öneriler. Elektronik Sosyal Bilimler Dergisi, 10(37), 244-266. Erişim adresi: https://dergipark.org.tr/tr/pub/

Özden, Y. (2002). Eğitimde dönüsüm, eğitimde yeni değerler (2. Bask1). Ankara: Pegem Akademi Yayınları.

Öztabak,O. (2015). Okul yöneticisi Seçme Atama ve Yetiştirme Sürecine Iliş̧kin Yönetici ve Ögrretmen Görüsleri. (Yüksek Lisans tezi). Uşak Üniversitesi Sosyal Bilimler Enstitüsü,Uşak.

Peker, Ö. (1994). Yönetici eğitimi. Ankara: TODAIE Yayınları.

Sungur, N. (1992). Yaratıc dïş̈̈nme. Ankara: Say Yayınları.

Şimşek, A. (2013). Sosyal bilimlerde araştırma yöntemleri (2. Baskı). Eskişehir: Anadolu Üniversitesi Yayınları.

Taymaz, H. (1986). Okul yönetimi ve yönetici yetiştirme. Ankara Üniversitesi EğitimBilimleri Fakültesi Dergisi, 19(1), 123-135. Erişim adresi: https://dergipark.org.tr/tr/pub/auebfd/issue/48473/614647

Taymaz, H. (2003). İlkögretim ve ortä̈gretim okul müdürleri için okul yönetimi (7. Baskı). Ankara: Pegem Akademi Yayınları. Tortop, N. (1994). Personel yönetimi (5. Bask1). Ankara: Yarg1 Yayınları.

Töremen, F. ve Kolay, Y. (2003). İlköğretim okulu yöneticilerinin sahip olması gereken yeterlikler. Milli Ĕğtim Dergisi, 160. Erişim adresi: http://dhgm.meb.gov.tr/yayimlar/dergiler/Milli_Egitim_Dergisi/160/ adresinden 1 8.08.2019.

Vergili, Ö. (2015). Eğitim kurumlarna yönetici seçme, yetiştirme ve atamaya ilişkin okul yöneticilerinin görüsleri (Batmn İiii Örmeği.) (Yüksek Lisans Tezi). Zirve Üniversitesi Eğitim Bilimleri Enstitüsü, Gaziantep.

Yeloğlu,D. (2008). Eğitim kurumlarna yönetici seçme ve atamaya ilişkin okul yöneticilerinin görü̈lerinin değerlendirilmesi. (Yüksek Lisans Tezi). Selçuk Üniversitesi Sosyal Bilimler Enstitüsü, Konya.

\section{EXTENDED ABSTRACT}

It will be beneficial for the candidate administrators to learn the reasons for the administrative staff's preference and to prefer them with this awareness. Besides, it is vital that the criteria to be used in the selection of the administrators who take on this important task should be determined very well, and they should be treated carefully and selectively. For these reasons, it was aimed to examine the administrators' reasons for choosing administration positions and their views on the selection of administrators, who work in the state secondary schools in the city center of Rize (principal, the head vice-principal, and viceprincipal).

The descriptive analysis model was used for this research, which aims to examine the administrators' reasons' for choosing administrative staff and their opinions about the administrator selection. The population of the research consists of 80 administrators working in the schools of the Ministry of Education in the center of Rize in the academic year 2019-2020. In the research, it was aimed to reach the entire population. However, six of the 80 administrators could not be reached due to their being attendant or in permission. Therefore, it covers $92.5 \%(\mathrm{f}=74)$ of the research population. Interviews were done with 18 administrators drawn from the population using the simple random sampling method. Frequency (f) and percentage (\%) tables were created based on the data obtained in the analysis of objectives in the research. Opinions of the participants were recorded in written form. In the research, the Chi-Square Test was used in the analysis of the compatibility between the responses given to the items. As a result of the interviews, a classification was made according to the frequency of the administrators' responses to the questions. 
Considering the opinions regarding the determination of the graduates who are required to apply to the administrative staff, it is seen that the option of teachers trained in all branches comes to the fore. More than half of the participants are of the opinion that the selection of administrators to be appointed to educational institutions should be made by an examination. The majority of the participants think that the administrators should be selected by an exam to the educational institutions because it is a fair and objective practice. More than half of the participants are of the opinion that the student selection and placement center should prepare and apply the administrator selection exam to educational institutions. More than half of the respondents who think that an interview exam should be applied to the educational institutions for the selection of administrators are in favor of that the selection interview for the educational institutions should be applied by the ministry and by the joint commission of the ministry and universities. In the evaluations of administrators' appointments to educational institutions, the criterion of "term of service" has been given more importance among the criteria that can be used other than exam and interview. The criterion that "administrators must have an education" is given more importance in view of the need for training before the administrators are assigned in educational institutions. The criterion of "the service should be limited" in the opinions about the limitation of the working hours of the administrators in the same institution has been given more importance. It is seen that there is a relationship between the way of choosing an administrator for educational institutions and the interview exam for administrators to be appointed to educational institutions.

Participants specify what features administrators should have as patience, empathy, common sense, justice, sincerity, tolerance, merit, professional knowledge, vision, predictability, farsightedness, and diligence. Participants determine the achievement criteria as ensuring student, parent, and personnel satisfaction, the establishment of the corporate culture of corporate identity, in-house happiness, creating a safe and peaceful working environment in the administration of educational institutions. Except for the exam and interview, the participants state that criteria should be used in the administrative evaluation form, especially in terms of the service period, national and international projects, participation in community service activities, and in-service training. Participants state that administrators to be assigned in educational institutions should receive training before they can start working. A relationship was found between the branch and the reasons for the administrative staff's preference. A relationship was found between the way in which the administrator is selected and the interview exam.

The characteristics that administrators should have can be determined by taking the administrators' opinions at all educational levels throughout the province. These determined features can take place as a criterion in the selection and assignment of administrators. The criteria in the administrator evaluation form used in the re-assignment of the administrators can be reconstructed in a way that is agreed upon by the majority of administrators, and the determined criteria can be determined more fairly. Candidate administrators may perform practical internships beside the administrator in an educational institution who are experienced, successful, and exemplary. Questioning why the teachers working in the verbal field in the branches preferred the administration staff more can be questioned again with any of the variables such as gender, additional course fees, professional satisfaction, and professional career. It is recommended that the interview and written exams should be applied in re-assignments since the way of selecting administrators for educational institutions is related to the fact that there is a relationship between the status of being with and without an exam and the interview exam for administrators to be assigned to educational institutions. 